\title{
Persepsi Mahasiswa Pendidikan Bahasa Indonesia Terhadap Whatsapp Grup Sebagai Media Pembelajaran di STKIP Muhammadiyah Manokwari
}

\author{
Irma Suriani, Juni Syaputra*, Kartini \\ STKIP Muhammadiyah Manokwari, Indonesia \\ *junisyaputra09@gmail.com
}

\begin{abstract}
The purpose of this research is to know the perception of Indonesian students towards whatsapp group as a learning media and know the role of whats App group as an effective learning media. In this research will use qualitative approach with the aim to know the real or natural condition of the event or phenomenon that is happening. Quantitative method used in this research is survey study using questionnaire. The results of research on students' perception of the learning process through whatsapp group, with the results of perception with $75.7 \%$ with the sound of questions Lecturers provide an opportunity for students to ask and discuss through whatsapp group, mahsiswa agreed to the question so that their perception is good and agreed keltika lectures conducted through online. While the lowest perception is in question 'your level of understanding in general of the course presented through whatsap gerup" with a percentage of 45.9\% agree. So students' understanding of the material submitted through whatsapp grus moderate category. So the learning process through wahatsapp group can be done to effectively the number of meetings during lectures.
\end{abstract}

Keywords: perception; students; whatsapp group; effective

\begin{abstract}
ABSTRAK
Tujuan dilakukan penelitian ini untuk mengetahui persepsi mahasiswa bahasa Indonesia terhadap whatsapp grup sebagai media pembelajaran dan mengetahui peran whatsApp grup sebagai media pembelajaran efektif. Dalam penelitian ini akan menggunakan pendekatan kualitatif denga tujuan untuk mengetahui kondisi yang sesungguhnya atau alami dari kejadian atau fenomena yang sedang terjadi. Metode kuantitatif yang digunakan dalam penelitian ini adalah studi survei dengan menggunakan angket. Hasil penelitian persepsi mahasiswa terhadap proses pembelajaran melalui whatsapp grup, dengan hasil persepsi dengan $75,7 \%$ dengan bunyi pertanyaan Dosen memberikan kesempatan kepada mahasiswa untuk bertanya dan berdiskusi melalui whatsapp grup, mahsiswa menyetujui pernyatan tersebut sehingga persepsi mereka baik dan setuju keltika perkuliahan dilakukan melalui daring. Semementara persepsi yang paling rendah terdapat pada pertanyan 'tingkat pemahaman anda secara umum terhadap mata kuliah yang disajikan melalui whatsap gerup" dengan persentase 45,9\% setuju. Jadi pemahaman mahasiswa terhadap materi yang disampaikan melalui whatsapp grus berkategori sedang. Jadi proses pembelajaran melalui wahatsapp grup dapat dilakukan untuk mengefektifkan jumlah pertemuan selama perkuliahan.
\end{abstract}

Kata Kunci: persepsi; mahasiswa; whatsapp grup; efektif

Submitted May 12, 2021 | Revised Jun 08, 2021 | Accepted Jun 14, 2021

\section{Pendahuluan}

Perkembangan teknologi akan menjadi tantangan khusus dalam duania pendidikan tidak hanya sebatas mengetahui akan tetapi dituntut untuk mampu dalam segala bidang. Untuk mengoptimalkan proses perkuliahan tentunya teknologi memiliki peran besar. Dengan teknologi perkuliahan dapat berlangsung dengan baik contohnya ketika Dosen berhalangan hadir untuk perkuliahan tatap muka dapat dilakukan secara online.

Sistem perkuliahan online ini dapat dilakukan dimana saja dan kapan saja dan dapat menghemat waktu dan tenaga. Sesuai dengan peraturan Pemerintah no109 tahun 2013tentang penyelenggaraan pendidikan jarak jauh pada pendidikan tinggi menjelaskan bahwa tujuan pencapaian pembelajaran jarak jauh harus sama dengan tujuan pencapaian pembelajaran sistem tatap muka (Erin \& Anggita, 2018). Erin dan Anggita mengungkapkan tujuan adanya kuliah online adalah menciptakan adanya proses belajar-mengajar antar dosen dan mahasiswa yang lebih praktis, dimana dosen dan mahasiswa dapat 
melaksanakan perkuliahan dimanapun tampa kenal jarak, memberikan kesempatan mahasiswa untuk tidak hadir perkuliahan secara konvensional, menjadikan mahasiswa lebih mengenal TIK, menjadikan mahasiswa lebih mandiri dalam belajar dan memahami informasi oleh dosen, serta memudahkan mahasiswa untuk berintraksi dengan dosen mengenai materi kurang dipahami oleh mahasiswa tersebut.

Perkembangan zama memang merubah semua yang sifatnya tradisional menjadi modern. Dahulunya kita belajar dan mencari ilmu pengetahuan secara manual dengan cara atang ke perpustakaan sekarang sudah berubah dengan menjadi teknologi. Dari kedua cara mendapatkan ilmu pengetahuan tersebut, tentunya memiliki dua sisi yang saling menguntungkan. Misalnya dengan menggunakan system tradisional kita mendapatkan pengetahuan secara langsung dengan memanfaatkan buku yang ada di perpustakaan. Sementara dengan menggunakan teknologi yang dalam hal ini teknologi digital banyak kemudahan yang didapatkan diantaranya, waktu yang digunakan lebih efisien, aksas pengetahuan dapat dilakukan kapan saja dan dimanna saja.

Suatu teknologi tentunya dapat mebantu meringankan benyak pekerjaan, menhemat tenaga dan waktu. Tidah hanya sebatas meringankan semua pekerjaan tentunya akan ada orang yang akan merasa kesulitan dalam menggunakan teknologi yang dimaksud. Contohya di STKIP Muhammadiyah Manokwari penggunaan teknologi akan menuai pro dan kontra apalagi digunakan sebagai media pembelajaran.

Proses pembelajaran yang dialmi mahasiswa di STKIP Muhammadiyah manokwari selama ini tergolong model pembelajaran konvensional dimana masih banyak dosen yang hanya memanfaatkan satu teknologi LCD saja dalam proses perkuliahan yang basisnya tetap bertatap muka. Dengan hanya memanfaatkan teknologi LCD ketika menyampaikan materi perkuliahan dirasa kurang efektif dikarenakan kondisi dosen dan mahasiswa. Salah satu permasalahan yang diahadapi ketika dosen tidak bisa melaksanakan proses perkuliahan dikarenakan dengan berbagai alasan sehingga jumlah pertemuan perkuliahan tidak maksimal.

Pemanfaatan media pembelajaran yang tepat akan memberikan kemudahan bagi mahasiswa untuk memahami materi perkuliahan yang disampaikan oleh seorang dosen/guru. Media pembelajaran memiliki peran penting dalam kelangsungan proses pembelajaran yang diharapkan untuk mencapai hasil yang maksimall. Menurut Hayati, dan Harianto (2017) media yang dapat membantu penyerapan melalui pandangan sehingga pengetahuan keteramoilan, atau sikap dapat dibangun pada kondisi yang membuat siswa mampu membantu mencapai tujuan belajar merupakan pengertian media pembelajaran audio visual. Penelitian yang dilakukan oleh Putri \& Sibuea (2014) dengan hasil penelitian kehadiran media pelajaran interaktif yang dibuat dengan software macromedia flas 8 dalam proses belajar mengajar telah membuat suasana yang berbeda dalam kelas. Materi yang dulunya diajarkan dengan ceramah dan hanya monoton dapat divariasikan dengan menampilkan tayangan berupa integrasi tesk, suara, gambar bergerak dan video. Semakin baik media pembelajaran yang diterapkan maka semakin baik kualitas pembelajaran.

Oleh kerena itu peliti akan mamanfaatkan Whatsapp grup sebagai solusi proses pembelajaran jarak jauh. yang belum memanfaatkan teknologi sebagai media pembelajaran. Sementara Yusmita dkk (2018) juga mengemukakan bahwa Whatsapp adalah aplikasi pesan untuk smartphone dengan basic mirip BlackBerry Messenger yang dimana kegunaan Whatsapp sendiri adalah sebagai media social chat dimana bisa saling tukar informasi antar pribadi maupun dalam grup. Dengan pemanfaatan Whatsapp grup dalam proses perkuliahan tentunya akan menimbulkan persepsi atau anggapan, yang berbeda-beda dari mahasiswa. Oleh karena itu penelitian itu, penelitian ini penting dilakukan dengan focus penelitian terhadap persepsi mahasiswa bahasa Indonesia terhadap WhatsApp Grup sebagai media pembelajaran.

Ada beberapa hasil penelitian yang telah dilakukan sebelumnya dengan hasil pemanfaatan whatsapp gerup sebagai media pelajaran seperti yang dilakukan oleh Utomo dan Moh. Ubaidillah (2018) melakukan penelitian dengan judul "Pemanfaatan Aplikasi Whatsapp Pada Pembelajaran berbasi Masalah Untuk Mata Kuliah Akutansi Internasional di Universitas PGRI Mandiun” hasil penelitian 
yang diperoleh penerapan model pembeljaran berbasis masalah dengan menggunakan aplikasi whatsapp berpengaruh atau berdampak positif yang ditujunjukkan hasil belajar mahasiswa untuk mata kuliah akutansi internasional berada di atas kriteria capaian yang ditetapkan. Mahasiswa lebih mudah dalam komunikasi, koordinasi, dan diskusi sebelum melakukan persentasi tanpa harus bertemu secara langsung. Lestari (2021) juga melakukan penelitian dengan hasil penelitian menunjukkan bahwa guru tela memanfaatkan whatsapp sebgai media pelajaran dalam menunjang kegiatan pembelajaran dalam jaringan dengan memanfaatkan fitur yang tersedia seperti foto, vedio, dokumen dan vedio call. Kemudian dalam pelaksanaan pemanfaatan whatsapp sebgai media pelajaran terdapat beberap hambatan yaitu ganguan sinyal, momori hp penuh, kurangnya intraksi, sulit mengetahui keseriusan belajar peserta didik, kurangnya motivasi belajar peserta didik, fasilitas pendukung belajar peserta didik, kurangnya motivasi belajar peserta didik, fasilitas pendukung pembelajaran online, dan sulit memahami materi yang diberikan.

Persepsi merupakan pandangan terhadap suatu hal yang dilihat, didengar dan dirasakan sehingga menimbulkan anggapan positif dan negatif. Persepsi dapat dikatakan sebagai sebuah proses masuknya pesan atau informasi kedalam otak manusia yang terintegrasi dengan pikiran, perasaan dan pengalaman-pengalaman individu (Akbar, 2015). Persepsi merupakan kecendrungan seseorang terhadap sesuatu dalam ranah relatif, artinya persepsi individu terhadap sesuatu itu akan berbeda-beda berdasarkan persepsi dari masing-masing orang (Nugraha, 2015). Menurut Robbin (dalam Novayanti dkk, 2017) menyatakan bahwa persepsi merupakan penilaian atau tanggapan seseorang terhadap objek atau kegiatan tertentu.

Penelitian yang dilakukan oleh Maulana dan Hamidi (2020) dengan judul penelitian "Persepsi Mahasiswa terhadap Pembelajaran Daring pada Mata kuliah Praktik di Pendidikan Vokasi" hasil penelitian yang ditemukan pada saat pandemic covid-19 tidak hanya terbatas pada pendidikan tinggi, pendidikan vokasi pun yang lebih mengutamakan beban mata kuliah praktek/keterampilan dapat melaksanakan pembelajaran daring. Terlihat dari persepsi positif mahasiswa terhadap pembelajaran daring berdasarkan aspek belajar mengajar, kapabilitas (kemampuan dosen), dan sarana dan prasarana. Namun demikian, pembelajaran daring masih terkendala oleh aksis internet yang masih terbatas khususnya di daerah Rural dan kondisi ekonomi mahasiswa yang terbatas sehingga tidak memiliki perangkat yang memadai untuk mengakses aplikasi pada pada pembelajaran.

Yanti, et al. (2017) melakukan penelitian dengan judul "Analisis Faktor-faktor yang mempengaruhi Persepsi Masyrakat dalam Pembangunan Hutan Tanaman Rakyat pada KPH Gedong Wani” dengan hasil penelitian tingkat persipsi masyarakat terhadap program pembangunan HTR tergolong dalam kategori sedang. Masyarakat merasa mendapakan manfaat dengan adanya program ini yaitu jaminan keamanan. Aturan yang ditetapkan oleh pemerintah juga tidak memberatkan masyarakat, seperti dalam hal pengurusan ijin berserta persyaratan dan juga jenis tanaman yang telah ditetapkan. Faktor-faktor yang berpengaruh nyata dalam mempengaruhi persepsi masyarakat terhadap program pembangunan HTR adalah pendidikan formal, pendidikan non formal, pendidikan informal, luas lahan HTR, pendapatan perbulan, kesedian info, intensitas penyuluhan, semakin tinggi tingkat pendidikan terdapat kecendrungan semakin meningkat persepsi. Pendidikan informal yang semakin banyak dilakukan menyebabkan semakin tinggi persepsi. Semakin sempit lahan, persepsi masyarakat semakin tinggi. Semakin tinggi pendapatan seamkin tinggi persepsi masyarakat dalam hal ketersedian info dan intensits penyuluhan, semakin tinggi kesediaan info dan intensitas penyuluhan semakin tinggi persepsi masyarakat pembanunan HTR.

Jadi, dapat disimpulkan bahwa yang dimaksud dengan persepsi merupakan kecerdrungan seseorang dalam memberikan penilaian secara terintegrasi dengan pikiran, perasaan terhadap benda atau objek sehingga menimbulkan anggapan secara positif atau negatif tergantung pada persepsi masng-masing individu. Menurut Walgito (dalam Faudy Akbar, 2015) mengemukakan beberapa paktor yang mempengaruhi persepsi seseorang diantaranya (1) objek yang dipersepsi, menimbulkan stimulus 
yang mengenai alat indra atau reseptor. Stimulus dapat datang dari luar individu yang mempersepsi, tetapi juga dapat datang dari dalam diri individu yang bersangkutan yang mengenai syaraf penerima sebagai reseptor. (2) alat indra syaraf dan susunan syaraf, alat indera atau reseptor merupkan alat untuk menerima stimulus yang diterima reseptor ke pusat susunan syaraf, yaitu otak sebagai pusat kesadaran. (3) Perhatian, untuk menyadari atau dalam mengadakan persepsi diperlukan adanya perhatian, yaitu merupakan lagkah utama sebagai suatu persiapan dalam rangka mengadakan persepsi.

Wahatsapp merupakan salah satu media sosial saat ini banyak yang menggunakan untuk kepentingan bersosialisasi maupun sebagai penyampaian pesan baik oleh individu maupun kelompok (Trisnaini, 2017); (Sukrillah, et al, 2017) Menjelaskan bahwa aplikasi whatsapp khususnya fitur whatsapp grup dirasa edial digunakan sebagai sarana diskusi dan penyebaran informasi akademik di lingkungan perguruan tinggi. Jadi, whatsapp grup merupak aplikasi yang dapat membantu banyak orang terutama anggota grup untuk mendapatkan informasi secara langsung dan mudah. Dalam penelitian ini whatsapp grup akan peneliti gunakan sebagai media pembelajaran epektif dalam menigkatkan proses perkuliahan.

Media pembelajaran berfungsi untuk menghadirkan objek yang terlalu mekro untuk dilihat langsung, misalnya memperbesar benda yang kecil, menyajikan peristiwa yang letaknya jauh, kompleks, rumit, yang berlangsung dengan sangat cepat atau lambat menjadi lebih sistematik dan sederhana Susarno (Primasari dkk, 2014). Sementara media pembelajaran menurut Sanjaya (2010) media pembelajaran adalah seluruh alat yang dapat dipakai untuk mencapai tujuan pendidikan seperti radio, televisi, buku, koran, majalah dan sebagainya.

Tujuan yang diajukan dalam penelitian ini adalah untuk mengetahui persepsi mahasiswa terhadap penggunaan wahatshap gerup sebagai media pembelajaran online. Sementara manfaat yang diharapkan dari penelitian ini, media pembelajaran wahatsapp gerup dapat digunakan sebagai media pembelajaran online dan dapat digunakan untuk mengefektifkan proses proses perkuliahan jarak jauh.

\section{Metode Penelitian}

Metode yang digunakan dalam penelitian ini adalah menggunakan metode deskriptif kualitatif yang digunakan untuk medeskripsikan fenomena yang telah ditemui dalam penelitian sehingga bersifat alamiah. Penelitian ini dilakukan di STKIP Muhammadiyah Manokwari pada mahasiswa pendidikan bahasa dan sastra Indonesia dengan jumlah responden sebanyak 68 mahasiswa. Teknik pengumpulan data dalam penelitian ini menggunakan angket tentang persepsi mahasiswa terhadap whatsapp grup sebagai media pembelajaran. Teknik pengumpulan data yang digunakan dalam penelitian ini dengan cara menyebarkan angket ke responden.

\section{Hasil dan Pembahasan}

Berdasarkan anget yang telah disebarkan dan analisis data yang telah dilakukan diperoleh data yang akan dibahas dalam penelitian ini yang disajiakan dalam bentuk table berikut

Tabel 1. Persepsi Mahasiswa Pendidikan Bahasa Indonesia terhadap Proses Belajar Mengajar Melalui Whattsap Grup

\begin{tabular}{clc}
\hline No & \multicolumn{1}{c}{ Pertanyaan Angket } & Persepsi \\
\hline 1 & $\begin{array}{l}\text { Petkuliahan daring dengan menggunakan whatsapp gerup } \\
\text { daptdiakses dengan mudah }\end{array}$ & $64,9 \%$ Setuju \\
2 & $\begin{array}{l}\text { Dosen menjelaskan arah dan tujuan dalam setiap pembelajaran } \\
\text { melalui whatsapp grup }\end{array}$ & $73 \%$ Setuju \\
3 & $\begin{array}{l}\text { Dosen memberikan kesempatan kepada mahasiswa untuk } \\
\text { bertanya dan berdiskusi melalui whatsapp grup }\end{array}$ & $75,7 \%$ Setuju \\
\hline
\end{tabular}




\begin{tabular}{clc}
4 & $\begin{array}{l}\text { Dosen memberikan respon terhadap pertanyaan yang muncul } \\
\text { selama perkuliahan melalui whatsap grup }\end{array}$ & $70,3 \%$ Setuju \\
5 & $\begin{array}{l}\text { Tingkat pemahaman anda secara umum terhadap mata kuliah } \\
\text { yang disajikan melalui whatsap gerup }\end{array}$ & $45,9 \%$ Setuju \\
6 & $\begin{array}{l}\text { Keaktifan dan attitude anda selama perkuliahan melalui } \\
\text { whatsapp grup }\end{array}$ & $62,2 \%$ Setuju \\
7 & $\begin{array}{l}\text { Saya memiliki perangkat/peralatan untuk melakukan perkuliahan } \\
\text { di rumah sesuai dengan petunjuk yang diberikan }\end{array}$ & $89,2 \% \mathrm{HP}$ \\
\hline
\end{tabular}

Berdasarkan analisis data penelitian yang telah dikalukan, makan akan dibahas secara mendalam tentang persepsi mahasiswa pendidikan bahasa dan sastra Indonesia terhadap proses perkuliahan dengan menggunakan whattsap gerup sebagai media pembelajaran epektif .

Pertanyaan angket dengan bunyi pertanyaan Petkuliahan Daring dengan menggunakan whatsapp gerup daptdiakses dengan mudah dengan persepsi 64, 9\% dengan jawaban setuju itu membuktikan bahwa mahasiswa dapat mengakses dan menggunakan whattsap gerup sebagai media pembelajaran dengan mudah. Sementara yang memiliki persepsi kurang setuju sebanyak 13,5\%, sangat kurang setuju $21,6 \%$ sengan persepsi bahwa perkuliahan dengan menggunakan whattsap gerup tidak dapat diakses dengan baik dikarenakan kendala jaringan dan pulsa data.

Pertanyaan angket dengan bunyi pertanyaan Dosen menjelaskan arah dan tujuan dalam setiap pembelajaran melalui whatsapp grup dengan persepsi mahasiswa $73 \%$ persepsi setuju, 16,2\% sangat setuju dan 10,8\% kurang setuju yang menandakan bahwa dosen selalu menyampaikan arah dan tujuan pembelajaran dengan baik sehingga mahsiswa memiliki anggapan baik dan memberikan respon terhadap dosen meskipun dilakukan perkuliahan dengan system online, akan tetapi dosen selalu memandu mahsiswa dalam pelaksanaan perkuliahan.

Pertanyaan dengan bunyi Dosen memberikan kesempatan kepada mahasiswa untuk bertanya dan berdiskusi melalui whatsapp grup dengan persepsi $75,7 \%$ setuju, dan $24,3 \%$ sangat setuju. Dari hasil persentase tersebut menunjukkan bahwa mahasiswa memiliki persepsi bahwa dosen selalu memberikan ruan dan kesempatan berdiskusi meskipun dilakukan secara online.

Pertanyaan angket Dosen memberikan respon terhadap pertanyaan yang muncul selama perkuliahan melalui whatsap grup dengan persepsi $70,3 \%$ setuju dan $29,7 \%$ sangat setuju. Berdasarkan persepsi tersebut yang secara keseluruhan setuju menunjukan bahwa mahasiswa berpandangan ke dosen yang menyampaikan materi melalui whatsapp gerup memberikan respon dengan baik sehingga perkuliahan dapat terlaksana secara maksiaml.

Pertanyaan angket "tingkat pemahaman anda secara umum terhadap mata kuliah yang disajikan melalui whatsap gerup" dengan persepsi mahasiswa 45,9\% Setuju. Berdasarkan hasil tersebut menunjukkan bahwa pemahaman mahasiswa terhadap materi perkuliahan yang disampaikan oleh dosen melalui whatsapp gerup mahasiswa memiliki persepsi bahwa pembelajaran yang dilakukan melalui whatsapp gerup dengan pemmahaman mahasiswa yang sangat rendah.

Sementara persepsi yang paling tinggi dengan bunyi pertanyaan Saya memiliki perangkat/peralatan untuk melakukan perkuliahan di rumah sesuai dengan petunjuk yang diberikan dengan jumlah $89,2 \%$. Dalam pertanyaan tersebut menunjukkan bahwa mahasiswa sebagaian besar menggunakan HP untuk mengakses whatsapp gerup.

Dari hasil koisioner yang telah disebarkan kepada mahsiswa bahasa Indonesia tebtang persepsi mereka terkait pelaksanaan proses pembelajaran dengan menggunakan whatsapp gerup, terlihat jelas bahwa pembelajaran online melalui whatsapp gerup kurang berjalan dengan epektif ketika menyampaikan materi dikarenakan kebanyakan mahasiswa mengiginkan pembelajaran dilakukan secara luring diabdingkan dengan darimg. Proses pembelajaran daring melalui whatsap gerup dapat dilakukan secara berganitian dalam meningkatkan kwalitas pembelajaran. Pembelajaran daring 
melalui whatsap gerup dapat dilakukan ketika dosen berhalangan hadir dan dapat mengefektifkan jumlah pertemuan pada saat perkuliahan.

Hasil penelitian di atas sejalan dengan penelitian yang dilakukan oleh Mu'minah dan M. Kurnia Sugandi (2020) dengan hasil penelitian penggunaan whatsapp grup merupakan salah satu yang dapat dimanfaatkan untuk membuat grup (kelompok belajar) yang berfungsi sebagai media pembelajaran daring, dimana pendidik dan peserta didik dapat bertukar informasi serta dapat membuat suatu forum diskusi belajar tentang materi pelajaran, tugas, atau sekedar memberi sapaan oleh pendidik kepada peserta didik. Prajana (2017) juga melakukan penelitian dengan hasil penelitian pemanfaatan aplikasi whatsapp dapat dimanfaatkan sebagai e-lerning yang merupakan salah satu karakteristik dan generasi teknologi web2.0 colabotration and sharing.

Dengan adanya hasil penelitian sebelumnya dan hasil penelitian ini memiliki hubungan antara persesi mahasiswa deng pemanfaatan whatsapp gerup sebagai media pembalajaran online dimasa pandemic civid-19 dan dapat digunakan sebagai media pembelajaran jarak jauh untum mengefiktifkan proses perkuliahan pada mata kuliah tertentu, terutama di STKIP Muhammadiyah Manokwari.

\section{Kesimpulan}

Dari hasil penelitian yang telah dilakukan bahwasannya pembelajaran yang dilakukan melalui whatsapp grup dapet menimbulkan persepsi yang berbeda-beda oleh mahasiswa. Persepsi yang paling dominan dalam proses pembelajaran didominasi oleh pertanyaan Dosen memberikan kesempatan kepada mahasiswa untuk bertanya dan berdiskusi melalui whatsapp grup. Sementara teknologi yang digunakan oleh mahasiswa dalam mengikuti proses pemebelajaran online adalah telepon selular.

\section{Daftar Pustaka}

Akbar, R. F. (2015). Analisis Persepsi Pelajar Tingkat Menengah Pada Sekolah Tinggi Agama Islam Negeri Kudus. Edukasia: Jurnal Penelitian Pendidikan Islam, 10(1).

Erin, E., \& Maharani, A. (2018). Persepsi Mahasiswa Pendidikan Matematika terhadap Perkuliahan Online. Mosharafa: Jurnal Pendidikan Matematika, 7(3), 337-344.

Harini, E., \& Taufiq, I. (2021). Persepsi Mahasiswa Pendidikan Matematika terhadap Perkuliahan Online di Masa Pandemi Covid-19. PRISMA, 10(1), 44-53.

Hayati, N., \& Harianto, F. (2017). Hubungan Penggunaan Media Pembelajaran Audio Visual dengan Minat Peserta Didik pada Pembelajaran Pendidikan Agama Islam di SMAN 1 Bangkinang Kota. Al-Hikmah: Jurnal Agama Dan Ilmu Pengetabuan, 14(2), 160-180.

Lestari, W., (2021). Pemanfaatan Whatsapp Sebagai Media Pembelajaran Dalam Jaringan Masa Pandemi Covid19 Di Kelas Vi Sekolah Dasar (Doctoral dissertation, Universitas Jambi).

Maulana, H. A., \& Hamidi, M. (2020). Persepsi mahasiswa terhadap pembelajaran daring pada mata kuliah praktik di pendidikan vokasi. Equilibrium: Jurnal Pendidikan, 8(2), 224-231.

Mu'minah, I. H., \& Sugandi, M. K. (2021). Utilizing The WhatsApp Group Application As A Media For Media Learning Im The Covid-19 Pandemic Time. BIO EDUCATIO:(The Journal of Science and Biology Education), 6(1).

Nugraha, U. (2015). Hubungan Persepsi, Sikap Dan Motivasi Belajar Terhadap Hasil Belajar Pada Mahasiswa Pendidikan Olahraga Dan Kesehatan Universitas Jambi. Cerdas Sifa Pendidikan, 4(1).

Sukrillah, A., Ratnamulyani, I. A., \& Kusumadinata, A. A. (2018). Pemanfaatan media sosial melalui whatsapp group FEI sebagai sarana komunikasi. Jurnal Komunikatio, 3(2).

Utomo, S. W., \& Ubaidillah, M. (2018). Pemanfaatan Aplikasi Whatsapp Pada Pembelajaran Berbasis Masalah Untuk Mata Kuliah Akuntansi Internasional Di Universitas PGRI Madiun. Kwangsan: Jurnal Teknologi Pendidikan. Jurnal Teknologi Pendidikan, 6(02), 199-211. 
Prajana, A. (2017). Pemanfaatan aplikasi whatsapp untuk media pembelajaran dalam lingkungan uin arraniry Banda Aceh. Cyberspace: Jurnal Pendidikan Teknologi Informasi, 1(2), 122-133.

Primasari, R., Zulfiani, Z., \& Herlanti, Y. (2014). Penggunaan media pembelajaran di madrasah aliah negeri se-Jakarta Selatan. Edusains, 6(1), 67-72.

Putri, I. P., \& Sibuea, A. M. (2014). Pengembangan media pembelajaran interaktif pada mata pelajaran fisika. Jurnal Teknologi Informasi \& Komunikasi dalam Pendidikan, 1(2), 145-155.

Sanjaya, W. (2010). Strategi Pembelajaran Berorientasi Standar Proses Pendidikan. Jakarta : Prenada Media Group.

Yanti, D. N., Banuwa, I. S., Safe'i, R., Wulandari, C., \& Febryano, I. G. (2017). Analisis faktor-faktor yang mempengaruhi persepsi masyarakat dalam pembangunan hutan tanaman rakyat pada KPH Gedong Wani. Jurnal Hutan dan Masyarakat, 61-74.

Yusmita, M., \& Zulfiah Larisu, S. (2018). Pemanfaatan Whatsapp Messenger sebagai media komunikasi antar pribadi mahasiswa ilmu komunikasi. Jurnal Ilmu Komunikasi UHO: Jurnal Penelitian Kajian Ilmu Komunikasi dan Informasi, 3(4). 